\title{
Imagining University/Community Collaborations as Third Spaces to Support Indigenous Language Revitalization
}

\author{
LEISA DESMOULINS \\ The National Centre for Collaboration in Indigenous Education \\ MELISSA OSKINEEGISH \\ The National Centre for Collaboration in Indigenous Education \\ KELSEY JAGGARD \\ The National Centre for Collaboration in Indigenous Education
}

\begin{abstract}
This paper explores the development of language instruction programs in universities to support Indigenous language revitalization. Eleven Indigenous educators shared rich insights through interviews. Their visions called for language learning that is functional, inseparable from land-based learning, and within multigenerational learning environments led by Elders. Building on these visions, the authors imagined a third space-an Indigenous-led, in-between space - to discuss the potentialities for universities and local communities to come together. The discussion offers strategies for a third space where universities support language revitalization in communities through co-programming, community-based courses in functional, immersive settings guided by Elders, and an online site for additional supports.
\end{abstract}

\section{Introduction}

It is through language that we communicate with the world, define our identity, express our history and culture, learn, defend our human rights and participate in all aspects of society, to name but a few. (United Nations, 2019)

The United Nations declared 2019 the international year of Indigenous languages to promote urgency in the revitalization and strengthening of Indigenous languages at regional, national, and international levels (United Nations, 2019). In Canada, the Truth and Reconciliation Commission's Calls to Action (2015) called upon the federal government to acknowledge Indigenous languages as an inherent right of Indigenous peoples, and to support "preservation, revitalization, and strengthening" (p. 2) initiatives across the nation. These calls counter the impacts and legacy of the Indian Residential School system.

Within the calls to action, Article 16 specifically calls upon post-secondary institutions to create and implement Indigenous language programs to support the drive towards Indigenous language reclamation. Considering this call, this article discusses the potential roles of post-secondary institutions to support communities' efforts to revitalize and strengthen Indigenous languages. 
There has been a growing number of language programs implemented in postsecondary institutions, either in the form of language learning courses and programs (Blair \& Fredeen, 2009; Fayant \& Sterzuk, 2018; Roy \& Morgan, 2008) or language instruction certifications (Czaykowska-Higgins, Burton, McIvor \& Marinakis, 2017; Johns \& Mazurkewich, 2001; McLeod, 2003). The focus within this article is on the extended development of language instruction programs in post-secondary institutions in collaboration with communities. The genesis of this article emerged from the ideas and experiences of Indigenous language (IL) speakers and instructors in the northwestern Ontario region who took part in a national project entitled the National Centre for Collaboration in Indigenous Education (NCCIE). As members of the project team at Lakehead University in Thunder Bay, Ontario the authors of this article interviewed IL speakers and instructors as part of NCCIE's project centering Indigenous education programs and initiatives across Canada. From these interviews, a vision emerged of the instructional and pedagogical approaches essential for effective and relevant IL instruction and learning. This vision caused us, instructors and scholars in a post-secondary institution, to reflect on how teacher education programs can support IL speakers in urban and remote communities. As a result, we imagined the creation of a "third space" within universities to foster collaboration and partnership amongst academic scholars and community instructors and knowledge holders. We acknowledge Bhabha's (1994) notion of third space, particularly Gutiérrez' (2008) work on third space within learning communities. In this article we build upon Gutiérrez, Bacquedano, and Tejada's (1999) framing of third spaces as transformational, specifically within university settings (Dudgeon \& Fielder, 2006). Importantly, we turn to Indigenous scholars' writing on the potential to improve programs intended for Indigenous peoples by learning from Indigenous peoples and building collaborative spaces (Haig-Brown, 2008; Lowan, 2012) within tertiary institutions.

Within the university context, Dudgeon and Fielder (2006) write about third spaces as " 'in between spaces' [of identity, innovative collaborations, and contestations]... with significant integration of diverse and living cultural knowledge into the educational experience" (p. 405). These spaces are not theoretical or static; rather, they are spaces for shared learning and action between university and community stakeholders. Haig-Brown (2008) asserts these are practical, living spaces. They are alive with the risk and vulnerability of genuine cultural engagement and exchange. She describes an ideal third space within the context of post-secondary institutions:

the space is fragile, the work is complex and fraught with the difficulties that new/old knowledges bring. For each person involved the work can only be what all thoughtful work demands: slow and rigorous, never yielding, and yet always open to learning (p. 264).

To explore this third space (Dudgeon and Fielder, 2006; Haig-Brown, 2008, Lowan, 2012) within IL instruction programs, this article juxtaposes Indigenous community educators' cultural knowledge and visions for language reclamation and strengthening with an existing Indigenous Language Instructors Program (ILIP) at a local university (both within northwestern Ontario) to imagine opportunities of a third space. In this article, we argue that IL instructors' programs need to infuse the cultural knowledge 
of Indigenous educators and knowledge holders' visions to remain relevant to and supportive of local communities' efforts to reclaim and revitalize languages. To provide further context this article begins with an introduction of the authors and the NCCIE project.

Introductions to Authors, Project, Region, and lLs

Beginning in 2017, Dr. Leisa Desmoulins, Regional Lead for NCCIE in the northwestern Ontario region, reached out to educators in Indigenous communities, organizations, and programs asking them to share initiatives and programs from early childhood education, K-12 schools, post-secondary, and community. She assembled a team of eight graduate students from Indigenous Education. They met with and interviewed over 40 individuals from communities within NWO. Dr. Melissa Oskineegish, Research Associate, joined the team during her final year of PhD studies in Education. Kelsey Jaggard joined the team the following year as a Masters of Education student assisting in administrative, research, and technology tasks. While the team comprised Indigenous and non-Indigenous educators, the authors of this article-Leisa, Melissa, and Kelsey-are non-Indigenous team members at Lakehead University, the site of the team from NWO.

NCCIE provides a digital platform for "listening to the voices of community members, educators, practitioners, knowledge holders, policymakers, and researchers with the aim of advancing the success of Indigenous education in Canada" (nccie.ca, n.d.). In addition to the interviews conducted and developed for the website, our team hosted a regional workshop for participants of the project and others working in Indigenous Education to further discuss their experiences, resources, and vision of Indigenous education and language instruction.

For NCCIE, the northwestern Ontario region is a geographically large area that spans from Michipicoten First Nation in the east to the Manitoba boundary with Ontario in the west. Northwestern Ontario is home to many remote First Nations, the furthest of which is Fort Severn. The NCCIE participants offer a sampling of the individuals, schools, and programs available in the region.

The three Indigenous languages spoken across the region derive from the Algonquin language family and include Ojibwe, Oji-Cree, and Cree (Cook \& Flynn, 2008; NAN, n.d.). According to O'Donnell and Anderson (2017) there are over 70 Indigenous languages within twelve distinct language families with a reported total of 260,550 language speakers across the nation. The largest language family in Canada are the Algonquin languages that are spoken in communities across Manitoba, Quebec, Ontario, Alberta, and Saskatchewan. Of the seven Algonquin languages, Cree, Ojibway, and OjiCree have the largest population of speakers with 96,575 Cree speakers across five provinces, 28,180 Ojibway speakers and 15,585 Oji-Cree speakers within Ontario and Manitoba (O'Donnell \& Anderson, 2017). Despite the larger numbers, Norris (2018) cautions that no Indigenous language can be considered safe from declining use or extinction because of an aging mother tongue population and the dominance of English in media, technology, schools, and work. In her analysis of the demographic trends of Indigenous languages, she found that with a growing younger population the percentage of mother tongue speakers is steadily aging and languages ultimately declining. The demographics of IL speakers affects Indigenous language communities across the nation (Cook \& Flynn, 2008). Alternatively, the number of people that are learning an Indigenous 
language as a second language is increasing - an encouraging direction for language revitalization and preservation (O'Donnell \& Anderson, 2016). This trend in second language learning happens primarily within schools. The need for instructors that are fluent in Indigenous languages and contribute to language revitalization positions this study.

\section{Theoretical Perspectives on Indigenous Languages}

In this section we first review literature on Indigenous language revitalization, which considers historical factors that led to the current state of Indigenous languages. Second, we compare three main approaches to Indigenous language teaching and learning methods (King \& Hermes, 2014).

\section{Indigenous Language Revitalization}

Hermes, Bang, and Marin (2012) draw on Vizenor's (2008) concept of survivance, which he describes as "an active sense of presence over absence, deracination, and oblivion" (p. 1). They describe language revitalization as a site of survivance: "a cross between survival and resistance in which ongoing processes of cultural continuity and change unfold" (p. 385). The historical and current colonial and assimilation policies have, and continue, to place Indigenous languages in a state of survival and resistance. Historical policies such as the Indian Act and the Indian Residential School System [IRSS] stripped Indigenous peoples of their rights, and put in place mechanisms to dismantle cultural beliefs, traditions, and practices to eradicate what the government termed as the 'Indian problem' (Royal Commission On Aboriginal Peoples [RCAP], 1996). The IRSS, which was officially in operation from 1831 until as recently as 1996 forced approximately 150,000 Indigenous children to attend the government funded church-operated schools (Miller, 2003; Truth and Reconciliation Commission (TRC), 2015). The IRSS was designed to assimilate students into a westernized system with the expressed mission to "kill the Indian in the child" (RCAP, 1996; TRC, 2015). Students who survived IRSS were often victims of physical, sexual, mental and emotional abuses that have had lasting impacts through intergenerational trauma felt by many Indigenous families and communities today (Bombay, Matheson \& Anisman, 2014). Part of the policies of the church-run schools was the forbiddance of students from speaking their Indigenous languages (Thorner \& Frohn-Nielsen, 2010). The IRSS affected the spirit of Indigenous peoples and tried to extinguish the learning spirit in the children. The harsh, and at times, inhumane punishments inflicted on students to prevent them from speaking their language have been documented within the RCAP (1996), TRC (2012), and many survivors' memoirs (e.g., Fontaine, 2010; Sellers, 2013; Sterling, 1992). A Tlingit man (cited in McIvor and Parker, 2016) shared the lasting impact of these punishments, he said: "Whenever I speak Tlingit, I can still taste the soap" (p. 23), bringing awareness to emotional, mental, and physical pain inherent within the mobilization of IL revitalization and reclamation.

Though the use of Indigenous languages is no longer prohibited in Canadian schools, the prominence of English or French in schools minimizes the opportunities for Indigenous language fluency and proficiency-even in elementary schools within Indigenous communities (Goddard, 2002; Kirkness, 1998; NAN, 2008). Indigenous language instruction is most commonly reduced to a single subject with a limited timeframe per week (Hinton, 2001). The ineffectiveness of this approach to language learning is

Language and Literacy 
argued by Indigenous educators and scholars (e.g., Greymorning, 2011; Blair \& Laboucan, 2006). Yet, Hinton (2001) acknowledges that recognition of Indigenous languages as a legitimate subject in schools has helped "many communities to erase the shame that generations of people have felt about their language and has created a readiness and eagerness in young people to learn their language and develop more intensive programs for revitalization" (p. 7). The next section describes common IL instruction methods.

\section{Indigenous language instruction}

Drawn from years of personal IL instructional experience, King and Hermes (2014) describe the three main approaches to Indigenous language learning as: immersion or submersion; book learning; and, performance. Immersion or submersion relies on observation and engagement with proficient language speakers who share "informal narratives" or "conduct ceremonies" (p. 272). King and Hermes view this approach effective for learners with some previous language knowledge as it is often reliant on specific contexts and can be difficult for everyday use. McIvor and Parker (2016) challenge this idea through their description of early childhood immersion programs. Their work of "language nests" describe immersion programs as spaces for young children "raised in the language through meaningful interaction with proficient speakers" (p. 24). While not widely used in schools across Canada, language nests originate from Maori language revitalization initiatives called Te Kohanga Reo (Bishop \& Berryman, 2006; Smith, 2003). One example of a language nest in Canada is the Chief Atahm school in Chase, British Columbia (Chief Atahm school, 2017). Scholars most often cite immersion programs as the most effective method of language instruction (Blair \& Fredeen, 2009; Greymorning, 2011; Hinton, 2001; McIvor \& Parker, 2016). The most often used approach to language learning is book learning, which King \& Hermes (2014) have described as a method that relies on "decontextualized vocabulary practice (e.g., flashcards), set phrases, and memorization of verb paradigms" (p. 273). It is understandable why this approach is used most often in schools as it fits into the subject-based approach of school programming and learning. Though King and Hermes note that this approach is effective for older second language learners who are immersed in western approaches to learning, many argue that language instruction must move away from book learning and into contextually rich environments with the guidance and expertise of fluent Elders (Moore, 2003; Neganegijig \& Breunig, 2007; Oskineegish, 2014; Rouvier, 2017). The third approach described by King and Hermes is the memorized performance. This approach is often heard during selfintroductions at events and gatherings. They argue that the use of language at events and gatherings can be beneficial as it provides practice in comfortable environments, and yet, the memorized speech limits a learner's opportunity to progress beyond the memorized performance of this introductory speech.

The findings in this article build on the language instruction approaches found in the literature as IL speakers and instructors share what they consider effective approaches in the revitalization and strengthening of language instruction in communities and schools across northwestern Ontario.

\section{Methodology}

This project uses an Indigenist approach to research. This strengths-based approach creates a vision for how communities and families want to be (Wilson, 2016). We borrow 
from Wilson's approach to imagine education and practice within the ILIP moving toward this vision described by community educators. Wilson's approach includes Indigenous and non-Indigenous researchers. As non-Indigenous researchers, we come from a position of relational accountability (Donald, 2012). Our accountabilities connect Leisa and Melissa to Indigenous family members - particularly our children - and all of us to Aboriginal communities, educators, and programs within NWO.

As noted above, for this study, we apply a conceptual frame of third space as a living space that seeks significant and genuine cultural integration of diverse and living cultural community knowledge to forge innovative collaborations with communities. These collaborations meld the evolving needs of communities with the academic integrity offered by university programs. Most significantly, third spaces privilege local community knowledges, perspectives, and experiences: they are Indigenous-led (Dudgeon \& Fielder, 2006) and we believe this includes Indigenous educators' visions for the evolving needs of language development in their communities.

\section{Methods}

The Regional Lead successfully gained ethics approval from Lakehead University for all researchers with the project. A team of eight completed forty interviews across northwestern Ontario. Interviews were completed over two academic years, between December 2017 and February 2019. The Regional Lead sent invitations to various Indigenous Education programs across Northwestern Ontario. Researchers selected many educators through prior relationships, a form of relational sampling (Wilson, 2008). Interviewees shared other programs, educators, or leaders they believed we should invite to take part. Once a list of programs and educator interviewees were selected, the Regional Lead provided graduate students with training and instruction on interview protocols. The NCCIE established protocols for interviews: 1) Initial invitation to take part in an interview; 2) Information on NCCIE, interview process, and description of the purpose of database; 3) Gift of tobacco and a small gift of thanks offered to educator participants for sharing their time and knowledge.

Research Assistants traveled to the program location and engaged in informal conversations (Kovach, 2009), often touring the program and facility. Some researchers are relational to some educator/participants. Audio or video interviews lasted approximately 20 minutes to one hour. We provided participants a copy of the questions prior to the interview. Interviewers asked five main questions:

1. Can you please describe the program?

2. What is the aim of the program?

3. How do you measure success of the program?

4. What is your vision of Indigenous Education?

5. What resources do you require to meet your vision?

The videos underwent a review process for quality of lighting, sound, permissions, and accuracy of information from participants. Then interviews were uploaded and edited by a tech team at First Nations University of Canada, in Saskatchewan. We sent the edited interviews to participants to preview prior to publishing on the NCCIE website. Notably, the NCCIE hosts videos on its website for participants and they can ask NCCIE to remove the video at any time. 


\section{Coding and Analysis}

Educators responses were coded by listening to participants' original videos as well as the condensed versions posted on the NCCIE site. Our coding was guided by tenants of grounded theory (Bryant \& Charmaz, 2007; Creswell, 2009; Savin-Baden \& Major, 2013). First, we selected educators that described Indigenous language programs. Our analysis began with initial coding of these language interviews that led to the development of multiple categories. This was followed by a process of constant comparison between participants' descriptions, perspectives, and visions to generate themes (Savin-Baden \& Major, 2013). For this article, we coded the responses for two of the four questions stated above (ie., educators' and knowledge holders' descriptions of their programs or initiatives and visions for moving forward), positioning codes within the theoretical framework of third space - known as axial coding (Creswell, 2009). Within this framework of third space, we sought to "look at Indigenous education from distinctly Indigenous perspectives" (NCCIE, 2019), employing Indigenous descriptions of theory and practices to gain an understanding of the praxis of Indigenous language education.

This article draws from the larger study and focuses on educators' responses to questions one and four from the interview guide above. We present the understandings of language learning from eleven participants who were interviewed by researchers within the NWO region for the NCCIE. These participants (Larry, Lisa, Mary, Shy-Anne, Jordan, Charlotte, Sarah, Vicky and Rachel from KOBE, and Bryanna, and John) work as educators or knowledge keepers within Indigenous language programs across northwestern Ontario and at Lakehead University. All community participants' visions emerged in their interviews. We sent their quotes and the final document to all participants for their review. We offered all participants a chance to offer their comments on the article. They responded by giving approval and making any clarifications or changes that they deemed necessary. Their comments strengthened this article. We introduce each of them next, in the order that they appear in the findings section that follows afterwards.

\section{Introducing the Educators and Their Videos}

Larry Beardy is an Oji-Cree speaker and instructor. He has taught language classes at elementary and post-secondary levels. He has also taught language speakers to become instructors within the Indigenous Language Instructors program (ILIP) at Lakehead University. From his many years of experience teaching students and instructors, Larry shares his reflections on effective language learning approaches to develop learners' language skills and promote language revitalization. Larry discusses his work as a language educator in a video for NCCIE called $A$ discussion on Anishinaabe language and instruction (https://www.nccie.ca/story/a-discussion-on-anishnaabe-language-andinstruction/).

Lisa Michano-Courchene is the Education Director of Biigtigong Nishnaabeg (previously known as the Ojibways of Pic River), a community on the banks of the Pic River along the north shore of Lake Superior. Biigtigong Nishnaabeg runs an elementary school (Endzi-gkinoohmaadin) and an alternative high school for students who choose not to attend the high school in the nearby town of Marathon). The elementary and secondary programs teach Nishnaabe world view and content. Lisa discussed the programs in condensed videos called Endzi-ghinoohmaadin (https://www.nccie.ca/story/pic-river-first- 
nation-school/) and Biigtigong Nishnaabeg (https://www.nccie.ca/story/pic-riversecondary-program/), respectively.

Mary Oskineegish is a graduate of the Native Language Instructors Program (now called the Indigenous Language Instructors Program, ILIP). She is a member of Nibinamik First Nation and a fluent Oji-Cree speaker. She is the Education Director of the Nibinamik Education Centre and has taught Oji-Cree in the community's elementary school. Mary discussed the Kindergarten to Grade 2 immersion program at the elementary school in a condensed video called Nibinamik First Nation Immersion Program (https://www.nccie.ca/story/nibinamik-first-nation-immersion-program/).

Shy-Anne Bartlett is an Anishinaabe woman and a member of the Red Rock Indian Band. She teaches for the Superior-Greenstone District School Board, a public board responsible for 15 schools located in Marathon, Ontario. Shy-Anne teaches Ojibwe language at a school for students at an elementary school within the Board. She discussed the Nelson Circle of Life series, based on Indigenous culture, language, and heritage from across Ontario. Shy-Anne worked with local Elders and language speakers to translate the Circle of Life series into the local dialect in a condensed video called Translation Project for the Circle of Life series (https://www.nccie.ca/story/translation-project-for-circle-oflife-series/).

Jordan Quequish is from North Caribou Lake First Nation. He is a fluent Oji-Cree speaker He conducted his video in Oji-Cree and provided his own translations into English. The Oji-Cree language is spoken by about 10,000 Indigenous peoples in northwestern Ontario (Statistics Canada, 2018). Oji-Cree is vulnerable to becoming an endangered language (Noori, 2013). In this condensed video, Knowledge for future Generations (https://www.nccie.ca/story/knowledge-for-future-generations/), Jordan offered his reflections on the knowledge he feels is important to pass along to future generations.

Charlotte Rae is an Elder from North Spirit Lake. She is a fluent Oji-Cree speaker who worked for the Keewaytinook Okimakanak Board of Education (KOBE) as an immersion instructor. Elder Charlotte conducted her video in Oji-Cree and provided her own translations into English. In this condensed video, Oji-Cree Education and Knowledge, Elder Charlotte, reflected on the importance of learning the language from an immersive approach and support of the parents and grandparents in the home and through their culture and from the Elders (https://www.nccie.ca/story/oji-cree-educationknowledge/).

Sarah Johnson is an Anishnaabe women who works for KOBE as the Native Language Perspectives Lead. She is a fluent Oji-Cree speaker. She worked with her team of Victoria Meekis (Oral Language Lead and Kindergarten Teacher) and Rachel Ombash of North Spirit Lake (Oji-Cree language teacher for grades 4 to 8 ) and Elders and other language speakers from across the region to populate an app for second language learners of Ojibwe, Cree, and Oji-Cree. These apps are available on the Apple Store and Google Play Store. The app tests speakers' oral language, retention of knowledge, and reading comprehension. Sarah shared her enthusiasm for using technology for learning language in a condensed video, KOBE Language Learning App (http://nccie.ca/story/kobelanguage-learning-app/).

Bryanna Scott is a Métis woman who works in the Aboriginal Education Department at the Faculty of Education at Lakehead University. She is the Coordinator of the Indigenous Language Instructors Program (ILIP). The ILIP is a teacher education 
program based out of Lakehead University in Thunder Bay, Ontario. It is a language program aimed at training fluent speakers in 1 of 4 Algonquin Languages (Ojibway, Cree, Oji-Cree, Delaware) to teach the languages in classrooms across Ontario. In this condensed video with John O'Meara, Indigenous Language Instructor's Program (https://www.nccie.ca/story/indigenous-language-instructors-program/), Bryanna shared her work with ILIP to accredit language educators certified with the Ontario College of Teachers. These instructors go back to their community's schools or any school across Ontario to teach the language.

John O'Meara served as the Dean of Education for the Faculty of Education from 2008 to 2019. He worked with the Native Language Instructors Program (now ILIP) in the Faculty of Education since 1985. John has taught in the program for many years. He shared his work training fluent speakers and the impact of the ILIP over many years in a condensed video with Bryanna Scott, Indigenous Language Instructor's Program (https://www.nccie.ca/story/indigenous-language-instructors-program/).

\section{Findings}

The genesis of this article emerged from the ideas, experiences and initiatives of Indigenous language speakers and instructors from the NCCIE project. We begin this section with a description of the main ideas about language instruction that emerged from their interviews.

\section{Functional Learning Environments}

Comparable to the literature on effective IL learning (e.g., Blair \& Fredeen, 2009; Hinton, 2001; McIvor \& Parker, 2016), many IL speakers and instructors advocated for an immersion (or submersion) approach to IL instruction and learning. Educator participants described this approach in either K-8 schools or in environments where learners were immersed with proficient speakers (often Elders) who could provide knowledge of language enriched with local, contextualized history. Larry described effective IL instruction as functional and natural. He explains that "where you teach and what you teach has to be local because that is the most effective and appropriate for the language learner to hear, speak, and be immersed in" and that functional language means "language that is used every day and in natural speech". Similar to IL scholars and educators (Greymorning, 2011; Hinton, 2001), Larry's experience in language instruction has led him to view nonimmersive IL courses or programs as ineffective for language learning proficiency. He compares previous classroom teaching methods with limited instruction time and preselected criteria as a wave, saying:

The way language has been taught for many, many years. It's a wave. Crash and burn I call it. Where students learn the language during the course of the year to some extent. So, they're riding the wave, they're going up, they're learning some teaching units and themes. Then they crash at the end of the year or at the end of the month when the unit is done. Pick up like a wave, then go down with a flop. Then, they start again... When they are in the program they are being exposed to the language, yes - there is learning happening but once it stops - they will lose it. When you do not use it, you lose it. If you are a language learner, there is another 
way of learning the language that enables you to become fluent and proficient in the language.

Larry's many years of experience have led to his teaching and learning philosophy that effective language programming includes opportunities for practice and use on an ongoing basis. His advocacy of language curriculum that needs to be in-sync at all levels and founded on the local dialect, which assists the learner to expand their language fluency continually.

\section{Inseparable From the Land}

Building on the impetus to move away from previous IL learning methods, two Education Directors from First Nations communities in northwestern Ontario re-imagine their communities' schools to align with the cultural practices and skills of the community. As Director, Lisa envisions the schools shifting away from the September to June school year to a "seasonal school year based on the season and the cultural activities associated with each season." Like Larry, she sees language as functional, or integrated with activities on the land. She said: "You can't take land-based learning without the language. They are connected."

Mary is a strong proponent of functional language learning through land-based activities. From her experience as an IL speaker and instructor, she shares: "I find that when you teach outside on the land, the students get more language out of the things that they see and they touch." The K-8 school in their community has integrated an immersion program for students in Kindergarten to grade 3. Instructors are language speakers who are qualified teachers through the Ontario College of Teachers (OCT) who teach alongside education assistants from the community. Within their immersion program, educators emphasize taking students outside to learn the language from and on the land. In the Fall, students "learn about plants". In the fall and spring, when community members harvest and prepare local animals for their families, they "teach kids the parts of the moose and geese". Mary works to integrate natural learning environments with language learning.

Thus, regardless of language - Ojibwe or Oji-Cree, community - urban or First Nation communities, or level; elementary or tertiary, these participants agree that language learning needs to be functional. Lisa and Mary expand on what functional learning looks like in their communities. Learning functionally happens alongside activities that connect learners to their communities. Lisa and Mary advocate for language learning embedded within activities that happen while learning on the land and in connection with community members.

\section{Multigenerational Learning Environments}

Participants also advocated for multi-generational learning environments. Within these environments, the importance of Elders emerged in two ways. In the first instance, Elders were essential to ensure language instruction connects to the dialect of the community. Shy-Anne explained her challenges as an Ojibwe language teacher in a school located near the Red Rock Indian Band's community:

As an Ojibwe teacher I often find that there are numerous, great resources out there; however, they are often in a dialect that is not conducive with the local dialect to 
the community, or they're not comprehensive, there's only one or two resources within there that we can use and they jump from level to level. And I've always dreamed as a teacher to have a resource that was comprehensive from a beginning language learner all the way to an emergent language learner, and beyond.

In the second instance, she described the importance for teachers to connect with local Elders who hold community knowledges and pedagogies:

As a teacher... understanding your students, especially from the language perspective, understanding the dialect within that region, respecting it, and being able to connect with the Elders in the community to ensure that what you are teaching is what's in their community.

Jordan expands on Shy-Anne's suggestion that Elders' knowledge is embedded in the community. He believes that language is entwined with cultural teachings, histories, worldviews, and perspectives of the community. He explains:

It's important we should see our Elders and to learn more of the language and how they used to live, because the way they lived, that's where the language is, that's where you can really learn the language. I think our young people really need that. That's our given way, how are ancestors communicated, I really believe that we need to learn and share the language with each other.

He added that: "If we do what our ancestors did and work together with love and kindness, I really believe that some of our people will carry on with the language." He imparted how the language of the ancestors teaches how to learn through a vision of love and kindness and by sharing the language.

Elder Charlotte reiterates this interconnection between Elders' knowledge and language learning. She integrates inter-generational connections of Elders and youth with learning language to accrue community knowledge and values: "We have to let younger generation know their own language, and the teachings of Elders, how Elders talk to them.... Elders, talk to them about their lives [and the] teachings in our Oji-Cree language."

These educators (Shy-Anne, Jordan, and Elder Charlotte Rae) provided a vision of the centrality of different generations within the learning environment. Elders and Ojibwe and Oji-Cree speakers provide guidance and knowledge of the dialect, share traditional knowledges held within their communities, and pass on values for learning and living. They describe how multi-generational learning is a key aspect of language revitalization and maintenance.

To recap, Larry's analogy of classroom learning environments as a wave that builds and builds only to crash, outlines the ineffectiveness of non-immersive language learning approaches. While this form of language learning builds a sense of accomplishment - as students grow their understanding and use of the language during the course - the "crash of the wave' happens when students leave the classroom environment and wait for their next course. Larry contrasts this method with what he calls a "functional learning environment", an immersive approach to language learning that features ongoing use and practice just like the non-immersive method. What differs is the use of language in natural 
environments in which students conduct activities within the community. Adding to Larry's ideas, Lisa and Mary describe what functional learning environments within their community might look like when language is inseparable from the land and teachers of the community. For them, functional language learning engages learners in activities that provide opportunities to use language for living. Shy-Anne, Jordan, and Elder Charlotte deepened the explanation of how functional learning environments are centred within community through knowledge keepers and Elder involvement. Emphasizing localized knowledge held by Elders' and language keepers', these educators highlight how multigenerational learning opportunities enable the sharing of cultural teachings, histories, worldviews, and perspectives of the community. Thus, functional learning approaches are community-led to benefit communities and prepare fluent, culturally-grounded language speakers who can pass along language and culture to the next generation.

While it is understood that functional learning environments, Indigenous languages' inseparability from the land, and multigenerational learning are imperative for language revitalization, other participants described ways to preserve language and knowledge using $21^{\text {st }}$ Century learning environments. This approach ensures that the knowledge and language that Elders hold is preserved and then passed along to learners when they are ready. Sarah Johnston and her team from KOBE developed an app to preserve the knowledge of the Elders and language speakers using local dialects from the region. NCCIE team members from NWO travelled to Sioux Lookout to attend the launch of the KOBE app. This language app presents words, phrases, and songs interactively to learn Ojibwe, Oji-Cree, and Cree. Importantly, the app also preserves the language of the Elders and knowledge keepers as a living legacy for future learners.

\section{Elders and $21^{\text {st }}$ Century learning}

Sarah Johnson, worked with Rachel, Victoria, Charlotte, and other Oji-Cree, Cree, and Ojibwe speakers from different First Nation communities to translate, and voice the words, phrases, and songs for the KOBE language app. Sarah describes the app as a resource that connects to the $21^{\text {st }}$ century learner, as most people use mobile technologies daily. She explains:

[People are] using it constantly, they cannot go without it right! This is one way to bring the language - it's in their hands. So, it's there, it's in their pockets.... If they have that app on their phone for example, or on their iPads, it's there, they can look it up, swipe and scroll and learn.

Sarah's vision is that by creating a language resource that is readily available to everyoneat any time, everyone can always learn something, even if it's starting with one word a day. As she says: "If they learn one word that's a bonus." The KOBE app is a different example of encouraging language learning as part of one's natural, everyday learning experiences. It moves away from classroom memorization and tests to active, engaged participation and use of language speaking and practicing the language on an as-needed basis and in a format familiar and heavily used by many in the $21^{\text {st }}$ century. The purpose of the app is not to be the primary language learning approach, instead, it serves as an alternative, functional resource that brings IL learning to many people at any time. 
Some of the NCCIE participants are former students of the Indigenous Language Instructors Program (ILIP) at Lakehead University - in the city of Thunder Bay, in northwestern Ontario. Programs such as ILIP meet the call for post-secondary institutions described in the TRC (p. 2); however, Lakehead (2019) seeks to expand relations with its community partners (p. 20). In the spirit of strengthening existing initiatives, we explored the role of post-secondary institutions in supporting IL speakers and instructors in urban and remote communities in the northwestern Ontario region. We wondered how these speakers and instructors' visions for their languages and their approaches to teaching and learning Ojibwe, Cree, and Oji-Cree in communities within NWO aligns with ILIP at Lakehead University. We begin this exploration by setting the contexts of ILIP in the Faculty of Education at Lakehead University.

\section{Indigenous Language Instructors Program at Lakehead University}

The ILIP began in 1981 in the Faculty of Education at Lakehead University. The program provides fluent speakers in the Algonquin languages (Ojibwe, Cree, and Oji-Cree) with an Indigenous Language Teaching Diploma (ILTD) in Indigenous language instruction. It is the only program in Ontario to provide teacher certification in an Algonquian language from the Ontario College of Teachers (Lakehead University, n.d.). The four-year program offers courses at the Thunder Bay campus of Lakehead University each summer in July. These courses cover Algonquian language structure, methodology, pedagogy, and practicum experience.

Concurrently, the ILIP provides a children's program with an afternoon day camp called Odaminowin. In the morning, children learn from the ILIP teacher candidates, as they practice what they learned in class. Teacher-educators and learners of ILIP may bring their children with them from their home communities to attend Odaminowin while they study. Other children and youth from Thunder Bay also attend the program.

Bryanna, explains that ILIP supports language revitalization and preservation by training fluent adult speakers to teach language at all classroom levels in Ontario. An example of what the TRC asked from post-secondary institutions, it provides students with a diploma specializing in Indigenous languages. Bryanna explained how the ILIP prepares learners to be instructors through classroom learning and practicum experiences:

Students are learning and developing their fluency, written and oral fluency in their language, as well as getting some of the key foundations for teaching. And our program is regulated by the Ontario College of Teachers, so there is a practicum component, where students are in classrooms and all the rules and regulations and policies and procedures around teaching in Ontario are exactly the same for our students teaching language as they would be for other teachers. Having that practicum experience in the classroom is a key component to our program to ensure that our students are prepared to teach the languages once they leave.

For Bryanna, one of the strengths of the ILIP is the students' ability to blend the theory of the classroom with practice in their practicum experiences in classrooms in their communities.

John, in his role as a language instructor, described the impact of the long-running ILIP program. He said: 
Well, first and foremost it's the impact that our graduates have. Because they really go out and they teach in a wide variety of settings right across the province and indeed across the country. And that is one of the key measures we use because it's visible, they're out in the community, they're teaching in school boards: they're contributors to maintaining and revitalizing their language. One of the important facets to the program, I think, is that we have had, we do have instructors who have taken the program who are themselves speakers of one of the three languages, who have come back to be instructors. So, there is kind of a cycle of ensuring credibility and authenticity in the program by really having those instructors. And we do make a point in having as many instructors who are Indigenous people in the program as we can. So, they teach a variety of courses - both the education part and the language structure part.

While students come from across Ontario and parts of Canada and the United States, the ILIP attracts many students from communities able to "grow and develop their language proficiency and teaching skills to be able to give back to their communities" (Bryanna).

Thus, the ILIP supports IL speakers to gain the certification needed to teach their language, provides a multigenerational environment with Elders, educators, and children interacting and learning together, and brings "diverse and living cultural knowledge into the educational experience" (Dudgeon \& Fielder, 2006, p. 405) through instructors who have taken the program who are themselves speakers of one of the Algonquian languages, and activities and gatherings held throughout the month of July. These instructors provide ongoing feedback as employees of ILIP.

To imagine further possibilities, we return to our central premise - What opportunities exist from the community educators' cultural knowledge and visions for language reclamation and revitalization to imagine a living and evolving third space within post-secondary programs such as ILIP, if any? In the discussion that follows, we consider several aspects to inform possibilities of a third space that melds educators' visions of Indigenous language instruction for their communities with the existing ILIP for potentialities.

\section{Discussion}

After listening to the ideas and experiences of IL speakers and instructors from the NCCIE project and looking at the current ILIP at Lakehead University, we offer several strategies for post-secondary institutions to consider when developing and implementing Indigenous language training programs. We see three strategies for ILIP: 1. Language programming in response to and in collaboration with local Indigenous communities; 2. programming that employs functional and immersive learning environments; and 3. supports to IL instructors and local communities using $21^{\text {st }}$ Century tools. While we present these as three discrete strategies for this article, we appreciate the "intrinsic interconnectedness of culture, language, land, and knowledgeable elders and teachers" (Lambe, 2003, p. 308). Central to this interconnectedness, Elders and language speakers and teachers are key to language transmission because they carry a full understanding of how Ojibwe is spoken appropriately-and needs to be an integral part of any language revitalization strategy (Noori, 2013). 


\section{Develop Programming in Partnership and Collaboration}

The first strategy is to develop programming in partnership and collaboration with Indigenous communities or organizations. This rests at the heart of developing relevant programming for language speakers within their communities. How can post-secondary institutions situated outside of Indigenous communities build an effective language program without localized, cultural knowledge as its basis? The development of partnerships between post-secondary institutions and local Indigenous communities is evident in a recent partnership.

In 2018, Queens University and the Tsi Tyónnheht Onkwawén:na Language and Culture Centre began a collaborative project. The project met with six nations of the Haudenosaunee (Mohawk, Oneida, Onondaga, Cayuga, Seneca, and Tuscarora) to plan a community-led language revitalization strategy. Participants discussed how to move IL instruction beyond the classroom, developing online resources to support language instruction and learning, and opportunities for the groups to meet together to discuss other potential joint projects. The groups created a certificate in Mohawk language, led by Haudenosaunee and facilitated and accredited through the university (Gaudreau, 2018). This project illuminates Dudgeon and Fielder's (2006) third space as an Indigenous-led, in-between space of collaboration and support.

Lowan (2012) asserts that creating a 'third space' requires the meeting of Western and Indigenous epistemologies and knowledge to enable a reconceptualization of a wider range of possibilities. The ILIP was developed in collaboration with communities and has fostered and accredited many IL teachers in school boards, in communities, and across the country. For the ILIP to re-conceptualize a wider range of possibilities, program staff could maintain ongoing contact and communication to learn from their graduates and from local Education Directors, Elders, and language speakers from surrounding First Nations communities. There is vast potential to work together as First Nations communities in NWO seek to repatriate education within their communities. Ongoing and diverse relationships would allow language programs such as the ILIP to evolve in response to communities' needs and through the guidance of Indigenous educators and language speakers, as programs continue to accredit IL instructors through the ILIP and the OCT.

\section{Functional and Immersive Learning Environments}

The second suggestion we offer is developing language training programs that provide functional, immersive learning environments. Like the collaborative project between Queen's University response to community needs and the Tsi Tyónnheht Onkwawén:na Language and Culture Centre, we see the growing desire for IL immersion programs in Indigenous communities in Canada (Monk, 2018), as the Education Directors, Lisa and Mary, for Biigtigong Nishnaabeg and Nibinamik respectively, stated above. Like Queens University, Lakehead serves as a regional university. It is well-positioned through its long-standing language instruction program, ILIP, to work with communities to accredit teachers within their schools. How could the ILIP accredit language teachers and support communities' needs more directly than it does?

In response, Hermes (2007) echoes what participants Larry, Lisa, and Mary say about using functional, immersive language environments when she writes: 
Ojibwe language has the potential to shift the paradigm of culture-based education from teaching about Ojibwe culture in and through English, to teaching through Ojibwe language. In this case, any content could be taught, and the way of understanding would still be culturally based. The focus of culturally based shifts from content to the medium of instruction. Although this may seem like a subtle shift, this would represent a paradigm shift. Indeed, the move from thinking about culture as curriculum content, to thinking through and creating in the Indigenous language would represent an entirely new focus for many Indigenous nations ( $\mathrm{p}$. 67).

Hermes' words support the educators' ideas of functional language and deepen the cultural dimensions inherent in language learning by learning within the community. Hermes contends that the shift in the medium of instruction changes the paradigm for both teachers and learners. This approach of thinking through and creating in Indigenous languages challenges university IL programs to shift instruction from content-focused in a classroom milieu to place-and-culture-focused within a community.

Morgan (2005) cautions that immersive language environments present challenges for research universities because of their many constituencies, bureaucratic structures, and policies. These structures and policies often serve to thwart innovation and partnerships. To address such limitations, Lakehead's (2019) Academic Statement asserts a commitment to students and communities in NWO to promote social and economic development. Like Hermes (2007), we believe post-secondary institutions should embrace the potentiality of immersion when it is evidence-based, requested by local communities, and meets the calls from the TRC to support "preservation, revitalization, and strengthening" (p. 2) of Indigenous peoples' visions for Indigenous languages in their communities.

Scholars assert immersion as a proven effective pedagogy for IL (Blair \& Fredeen, 2009; Hinton, 2001; McIvor \& Parker, 2016; McInnes, 2014). Universities have an opportunity to extend their IL teaching expertise into community-based learning environments. This shift requires them to move away from the Western subject-based approach of classroom settings and book learning prevalent in university learning environments. In the literature review above, scholars suggest that IL flourishes in contextually rich environments with the guidance and expertise of fluent Elders (Oskineegish, 2014; Moore, 2003; Neganegijig \& Breunig, 2007; Rouvier, 2017), which are best accomplished in community settings. These settings promote functional learning, which universities are challenged to provide within classroom settings.

By extending programming into functional spaces within communities like Biigtigong Nishnaabeg and Nibinamik, universities attend to the TRC Calls to Action to reverse the harms caused through colonization. Above we mentioned how the IRSS and Indian Affairs' policies forbade students from speaking their Indigenous languages and the ongoing damage to IL. Since that time, intergenerational language transmission has become infrequent for those living in or near urban areas, youth, and those seeking to learn an endangered language (Norris, 2018). In many cases, Indigenous languages are endangered or vulnerable to becoming endangered (Fishman, 2007; Norris, 2013). This presents real problems because Fishman advises that languages have the best chance for revitalization when communities: 
Start exactly where the mother tongue starts and try to aim at that. Even the school can help you aim at that. Another bit of advice is, do not concentrate along institutional lines. Most languages are not institutional, but informal and spontaneous. That is where language lives. Children live; they play; they laugh; they fall; they argue; they jump; they want; they scream (Fishman, 2007, p. 79).

Educational settings such as ILIP have taken up the challenge of accrediting IL teachers by creating teaching and learning centres for IL. However, to activate Fishman's recommendations for starting where the mother tongue starts means that "the enhanced systematic use of these languages within community- and school-based contexts is necessary to ensuring an integrated and authentic approach to language revitalization" (McInnes, 2014, p. 756), not within post-secondary institutions. Biigtigong Nishnaabeg and Nibinamik educators hold IL immersion as a vision for their children learning from their speakers and Elders within their communities. These educators' visions fit Lakehead's (2019) academic plan to adapt to a changing world, create new knowledge and pedagogies that support community-based learning, and contribute to the economic, social, and cultural needs of communities (p. 8).

\section{Providing Additional Supports}

Our third suggestion is for post-secondary institutions to think about providing additional supports to IL instructors during and after completing their language program. As language speakers graduate from teacher training programs and build their own language courses and programs, they need resources and support, as Shy-Anne mentions above. Her vision is to have resources that are "comprehensive from a beginning language learner all the way to an emergent language learner, and beyond" for her IL classes.

To meet IL classroom teachers' needs, Noori (2013) and Galla (2016) consider media sources to support IL at a distance. Galla (2018) considers the potential of media technology in ways similar to Haig-Brown's (2008) description of ideal third space. Galla explains, "The ability to generate language materials and resources 'in-house' —or by, for, and within the community - allows for control over the creation, development, production, publication, and distribution each and every step of the way" (p. 108-109). In this way, IL teaching and learning becomes a collaborative and transformative third space.

Galla (2018) describes another collaborative innovation through media technology with Hawaiian IL educators:

One such technology was Leokī (an electronic bulletin board system meaning 'powerful voice'), developed in 1995 by Hale Kuamo'o Hawaiian Language Center. Though no longer used, Leokī was known as one of the first bulletin board systems to operate exclusively in an Indigenous language (Hale, 1995; Warschauer \& Donaghy, 1997) - providing online support for Hawaiian language educators in Hawaiian immersion schools, Hawaiian language medium schools, and the broader community (p. 111).

Her example shows how a university IL programs like ILIP could contribute to community language revitalization through media technology for language resource sharing that is available and accessible on most university campuses. Some of these technologies may not 
be available in communities and/or to IL speakers who may be older and not familiar with this technology.

Sarah responded to this issue by recording IL Elders and speakers and putting their language into an app as an alternative, functional resource that brings IL learning to many people at any time. The app that Sarah Johnson and her team developed through KOBE is an opportunity to extend the use of digital technology and potential of the language learning app. Integrating digital technology increases the domains in which ILs are used and engaged (Galla, 2018, p. 113).

There are a range of possibilities for digital technology-audio-books and recordings, on-reserve radio programming, online dictionaries, electronic bulletin board system, localized language resources, podcasts, and more (Galla, 2018; Hermes, 2007). The ILIP could host an online site with IL resources in the three Indigenous languages of northwestern Ontario (Ojibwe, Cree, and Oji-Cree) to contribute to community efforts for language reclamation and revitalization and support language speaker graduates of the program. While it is vital for universities to support language revitalization, it always must be Indigenous-led for success. Fishman (2007) explains what programs in post-secondary institutions offer, but that ultimately language revitalization needs to be a shared endeavour:

The school has intellectuals in it. The school has a building, a budget, a time, and a place. Now it has to put the life of the language, not just the literacy of the language, not just the grammar of the language, not just the lexicon of the language, but the life of the language in the home and the community on its agenda if the language is going to be passed along (p. 81).

It is critical for post-secondary programs to support IL speakers and communities through digital technologies and to find ways to support the life of the language as well.

As the examples above illuminate, living and evolving third spaces require significant and genuine cultural integration and knowledge to forge innovative, ongoing collaborations with communities. These collaborations meld communities and their rich localized cultural knowledge of Elders and language speakers, natural learning environments, and evolving needs of communities with the academic integrity and infrastructure that university programs offer. These collaborations offer the potentiality of an Indigenous-led third space and communities' visions for language revitalization and strengthening. Further, they could contribute to universities' aspirations for communityengaged research as well as the calls to action from the TRC in meaningful ways that are led by communities. This is our shared history.

\section{Conclusion}

The rich insights that educators shared with us through their visions show the possibilities that emerge for IL Instructor Programs that are open to opportunities to imagine a third space within post-secondary institutions. To move forward, university educators must address the challenges inherent in a third space approach.

One challenge is that post-secondary language programs are situated within static institutions that report to external accreditation bodies: neither of these institutions are nimble and responsive to changing community contexts. Community educators have 
shown the value of functional approaches, immersive environments, and digital technology as vital for reclaiming and revitalizing Algonquin languages within northwestern Ontario.

Through their visions, educators described functional language learning approaches. They offered innovative pedagogical practices of Indigenous language instruction grounded in their local communities and language speakers and educators. These practices will aid Indigenous language instructor programs, such as the ILIP at Lakehead University, in offering programs that support communities' work in IL reclamation and revitalization. Importantly, educators' visions provide opportunities for the ILIP to re-imagine how it might support communities and meet the TRCs' calls to action. Drawing upon knowledge and experience of local Elders and knowledge keepers is a powerful pedagogical approach to bringing post-secondary programs into communities when they seek to promote a third space within Indigenous language instructor programs.

The stakes are high. If communities in NWO lose their first language speakers the languages cannot be revived. Universities that forge third spaces with local communities and through digital technologies will aid in transforming educational practices that support communities' efforts to reclaim and revitalize their languages while they still can.

\section{References}

Bhabha, H. (1994). The location of culture. London, UK: Routledge.

Bishop, R. \& Berryman, M. (2006). Culture speaks: Cultural relationships and classroom learning. Wellington, Aotearoa, NZ: Huia Publishers.

Blair, H., \& Fredeen, S. (2009). Putting knowledge into practice: Creating spaces for Cree immersion. Canadian Journal of Native Education, 32(2), 62-77.

Blair, H., \& Laboucan, B.J. (2006). The Alberta language initiative and the implications for Indigenous languages. Canadian Journal of Native Education, 29(2), 206-214.

Bombay, A., Matheson, K., \& Anisman, H. (2014). The intergenerational effects of Indian Residential Schools: Implications for the concept of historical trauma. Transcultural Psychiatry, 51(3), p. 320-338. doi:10.1177/1363461513503380

Chief Atahm School. (2017). T'selcéwtqen Clleq'mel'ten/Chief Atahm School. Retrieved from http://www.chiefatahm.com/

Cook, E., \& Flynn, D. (2008). Aboriginal languages of Canada. In W. O’Grady \& J. Archibald (Eds.), Contemporary linguistic analysis: An introduction (pp. 318-333). Toronto, ON: Pearson Longman.

Czaykowska-Higgins, E., Burton, S., McIvor, O., \& Marinakis, A. (2017). Supporting Indigenous language revitalisation through collaborative post-secondary proficiency-building curriculum. In W. Y. Leonard \& H. De Korne (Eds.). Language documentation and description (pp. 136-159). London, UK: EL Publishing.

Dudgeon, P., \& Fielder, J. (2006). Third spaces within tertiary places: Indigenous Australian studies. Journal of Community \& Applied Social Psychology, 16(5), 396-409.

Fayant, R., \& Sterzuk, A. (2018). Michif language revitalization within a post-secondary context. Canadian Diversity, 15(1), 18-21. Retrieved from https://www.ciim.ca/img/boutiquePDF/canadiandiversity-vol15-no1-2018_mod1y008j.pdf 
Fishman, J. (2007). What do you lose when you lose your language? In G. Cantoni, (Ed.). Stabilizing Indigenous languages (Rev. ed., pp. 71-81). Flagstaff, AZ: Northern Arizona University.

Fontaine, T. (2010). Broken circle: The dark legacy of Indian residential schools: A memoir. Toronto, ON: Heritage House.

Galla, C. K. (2016). Indigenous language revitalization, promotion, and education: Function of digital technology. Computer Assisted Language Learning, 29(7), 1137-1151. doi:10.1080/09588221.2016.1166137

Galla, C. K. (2018). Digital realities of Indigenous language revitalization: A look at Hawaiian language technology in the modern world. Language and Literacy, 20(3), 100-120.

Gaudreau, P. (2018. August 9). Breathing new life into Indigenous languages. Queen's Gazette. Retrieved from. https://www.queensu.ca/gazette/stories/breathing-newlife-indigenous-languages

Goddard, J. T. (2002). Ethnoculturally relevant programming in northern schools. Canadian Journal of Native education, 26(2), 124-133.

Greymorning, N. (2011). A language warrior's eighteen years of running a gauntlet. Canadian Journal of Native Studies, 31(1), 193-203.

Gutiérrez, K. D. (2008). Developing a sociocritical literacy in the third space. Reading Research Quarterly, 43(2), 148-164.

Gutiérrez, K. D., Baquedano-López, P., \& Tejeda, C. (1999). Rethinking diversity: Hybridity and hybrid language practices in the third space. Mind, Culture, and Activity, 6(4), 286-303.

Haig-Brown, C. (2008). Working a third space: Indigenous knowledge in the post/colonial university. Canadian Journal of Native Education, 31(1), 253-267.

Hermes, M., Bang, M., \& Marin, A. (2012). Designing Indigenous language revitalization. Harvard Educational Review, 82(3), 381-402.

Hermes, M. (2007). Moving toward the language: Reflections on teaching in an Indigenous- immersion school. Journal of American Indian Education, 46(3), 5471.

Hinton, L. (2001). Language revitalization: An overview. In L. Hinton \& K. Hale (Eds.) The green book of language revitalization in practice (pp. 3-18). San Diego, CA: Academic Press.

Johns, A., \& Mazurkewich, I. (2001). The role of the university in the training of native language teachers. In L. Hinton \& Hale, K. (Eds.). The green book of language revitalization in practice (pp. 355-366). San Diego, CA: Academic Press.

King, K. A., \& Hermes, M. (2014). Why is this so hard? Ideologies of endangerment, passive language learning approaches, and Ojibwe in the United States. Journal of Language, Identity, \& Education, 13(4), 268-282. doi:10.1080/15348458.2014.939029

Kirkness, V. J. (1998). Our peoples' education: Cut the shackles; cut the crap; cut the mustard. Canadian Journal of Native Education, 22(1), 10-15.

Kovach, M. (2009). Indigenous methodologies: Characteristics, conversations, and contexts. University of Toronto Press. 
Lambe, J. (2003). Indigenous education, mainstream education, and Native Studies:

Some considerations when incorporating Indigenous pedagogy into Native studies. American Indian Quarterly, 27(1\&2), 308-324.

Lakehead University (2019). Lakehead University's 2019-2024 Academic Plan.

Retrieved from https://www.lakeheadu.ca/sites/default/files/uploads/108/LakeheadAcademic\%20Plan\%202018-2023.pdf

Lowan, G. (2012). Expanding the conversation: Further explorations into Indigenous environmental science education theory, research, and practice. Cultural Studies of Science Education, 7(1), 71-81.

McInnes, B. (2014). Teaching and learning Ojibwe as a second language: Considerations for a sustainable future. Journal of Language Teaching and Research, 5(4), 751758.

McIvor, O., \& Parker, A. (2016). Back to the future: Recreating natural Indigenous language learning environments through language nest early childhood immersion programs. The International Journal of Holistic Early Learning and Development, $3,21-35$.

McLeod, Y. (2003). Change makers: Empowering ourselves thro' the education and culture of Aboriginal languages: A collaborative team effort. Canadian Journal of Native Education, 27(1), 108-126.

Miller, J. R. (1996). Shingwauk's vision: A history of Native residential schools. Toronto, ON: University of Toronto Press.

Monk, J. (2018, May 25). The power of immersion and bilingual schools for Indigenous language revitalization. Samuel Centre for Social Connectedness. Retrieved from https://www.socialconnectedness.org/the-power-of-immersion-and-bilingualschools-for-indigenous-language-revitalization/

Moore, P. J. (2003). Lessons on the land: The role of Kaska Elders in a university language course. Canadian Journal of Native Education, 27(1), 127-139.

Morgan, M. J. (2005). Redefining the Ojibwe classroom: Indigenous language programs within large research universities. Anthropology and Education Quarterly, 36(1), 96-103. https://doi.org/10.1525/aeq.2005.36.1.096

National Center for Collaboration in Indigenous Education (NCCIE) (n.d.). Retrieved from www.nccie.ca

Neganegijig, T., \& Breunig, M. (2007). Native language education: An inquiry into what is and what could be. Canadian Journal of Native Education, 30(2), 305-322.

Nishnawbe Aski Nation (NAN). (2011). Nishnawbe Aski Nation's report on the challenges and needs in kikinahamaagewin (education). Retrieved from: http://www.nan.on.ca/upload/documents/education-report-feb2012-final.pdf

Nishnawbe Aski Nation. (n.d.). About us. Retrieved from http://www.nan.on.ca/article/about-us-3.asp

Noori, M. (2013). Anishinaabemowin: Language, family and community. In L. Hinton (Ed.), Bringing our languages home: Language revitalization for families (pp. 118140). Berkeley, CA: Heydey Press.

Norris, M. J. (2018). The state of Indigenous languages in Canada: Trends and prospects in language retention, revitalization and revival. Canadian Diversity, 15(1), 22-31. Retrieved from https://www.ciim.ca/img/boutiquePDF/canadiandiversity-vol15no1-2018_mod1-y008j.pdf 
Noori, M. (2013). Anishinaabemowin: Language, family and community. In L. Hinton (Ed.), Bringing our languages home: Language revitalization for families (pp. 118140). Berkeley, CA: Heydey Press.

O'Donnell, V., \& Anderson, T. (2017). The Aboriginal languages of First nations people, Métis and Inuit: Census in brief. Statistics Canada Catalogue no. 98-200-X. Retrieved from https://www12.statcan.gc.ca/census-recensement/2016/as-sa/98200-x/2016022/98-200-x2016022-eng.cfm

Oskineegish, M. (2014). Developing culturally responsive teaching practices in First Nation communities: Learning Anishinaabemowin and land-based teachings. Alberta Journal of Educational Research, 60(3), 508-521. Retrieved from https://journalhosting.ucalgary.ca/index.php/ajer/article/view/55942

Rouvier, R. (2017). The role of Elder speakers in language revitalization. In W.Y. Leonard \& H. De Korne (Eds.) Language documentation and description, vol 14 (pp. 88-110). London, UK: EL Publishing.

Roy, H., \& Morgan, M. J. (2008). Indigenous languages and research universities: Reconciling world views and ideologies. Canadian Journal of Native Education, 31(1), 232-247.

Royal Commission on Aboriginal Peoples [RCAP] (1996). Report of the Royal Commission on Aboriginal Peoples, (vol. 3). Ottawa, ON: Minister of Supply and Services Canada.

Sellars, B., \& Harrison, M. (2013). "They called me number one”: Secrets and survival at an Indian residential school. Vancouver, BC: Talonbooks.

Smith, G.H. (2003). Indigenous struggle for the transformation of education and schooling. Proceedings of the annual meeting of the Alaska Federation of Natives (AFN) Convention. Anchorage, Alaska. Retrieved from http://www.ankn.uaf.edu/curriculum/Articles/GrahamSmith/

Sterling, S. (1992). My name is Seepeetza. Toronto, ON: Groundwood Books. Thorner, T., \& Frohn-Nielson, T. (Eds.). (2010). A country nourished on self-doubt: Documents in post-confederation Canadian history. Toronto, ON: University of Toronto Press.

The Truth and Reconciliation Commission of Canada [TRC]. (2012). They came for the children: Canada, Aboriginal peoples, and Residential schools. Retrieved from http://www.trc.ca/assets/pdf/resources_2039_T\&R_eng_web[1].pdf

The Truth and Reconciliation Commission of Canada [TRC]. (2015). Truth and reconciliation commission of Canada: Calls to action. Retrieved from http://trc.ca/assets/pdf/Calls_to_Action_English2.pdf

United Nations. (2019, January 12). 2019 International year of Indigenous languages.

Retrieved from https://www.un.org/development/desa/dspd/2019/01/2019international-year-of-indigenous-languages/

Vasquez, O. (1994). The magic of La Clase Magica: Enhancing the learning potential of bilingual children. Australian Journal of Language and Literacy, 17, 120-128.

Vizenor, G. (2008). Asthetics of survivance. In G. Vizenor (Ed.), Survivance: Narratives of native presence (pp. 1-24). Lincoln, Nebraska: University of Nebraska Press.

Wilson, S. (2008). Research is ceremony: Indigenous research methods. Black Point, NS: Fernwood Publishing. 
Wilson, S. (2016). Using Indigenist research to shape our future. In M. Gray, J. Coates, M. Yellow Bird, \& T. Hetherington. (Eds.). Decolonizing social work (pp. 311322). New York: Routledge.

\section{Author Biography}

Dr. Leisa Desmoulins has served as the Research Lead for NCCIE for the northwestern Ontario region since fall 2017. Many years ago, she married an Anishnaabe man and gained Indian status. Together they raised three Anishinaabe children in Thunder Bay. Family connections ground her in community-Biigtigong Nishnaabeg (formerly the Ojibways of the Pic River First Nation) and Thunder Bay, where she teaches undergraduate and graduate courses in the Faculty of Education at Lakehead University. Leisa's community-led Indigenous research uses researcher-practitioner collaborations to explore intersections between Aboriginal education, sovereignty, and action for justice.

Dr. Melissa Oskineegish is a research associate for NCCIE in the northwestern Ontario region. She is a recent graduate of the Joint $\mathrm{PhD}$ program in Educational Studies at Lakehead University whose dissertation examined the role of self-reflective practices in a mandatory Indigenous education course in teacher education. Prior to her graduate studies, she began her teaching career in a northern First Nation community where she was mentored by experienced educators who provided her with guidance on developing curriculum and pedagogical practices that were relevant and meaningful to the students she taught - an aim that influences her current work within Indigenous education research.

Kelsey Jaggard joined the northwestern Ontario NCCIE research team in its second year as a research assistant. She is working towards her Masters of Education with a specialization in Indigenous Education at Lakehead University. Her research will take her home to Alberta to investigate informal education in a provincial park and the effect of engaging with local Indigenous truths on its education practices. Prior to her graduate studies, she worked as an educator in the parks system and holds an Applied Ecotourism and Outdoor Leadership Degree from Mount Royal University. 